\title{
Intrinsic Elements and Sociological Criticism of Green Book Movie
}

\author{
K. Dian Rani*, I Made Winaya \\ English Department, Faculty of Arts, Udayana University \\ Email:kdianrani@gmail.com \\ Denpasar, Bali, Indonesia \\ *Corresponding Author
}

\begin{abstract}
The aims of the study were to find out the content of intrinsic elements of the Green Book movie and criticize the movie from sociological perspective. The study used qualitative method. It applied the theory of literature specfically intrinsic elements of drama proposed by Diniejko (2010) and sociological criticism proposed by Rapaport (2011). The results of the study were, firstly, the intrinsic elements found in the Green Book movie are plots, character, dialogue, setting, conflict, theme and motif which support the deeper understanding of the internal part of the movie. Secondly, by conducting a sociological criticism, it is found that the movie is related to the social condition of America in 1962 and it has correlation with the situation faced by American white and black nowadays.
\end{abstract}

Keywords: intrinsic, criticism, unequal, white, black

\begin{abstract}
Abstrak
Penelitian ini bertujuan untuk menemukan konten unsur-unsur intrinsik dari film Green Book dan mengkritisi film tersebut dari sudut pandang sosial. Metode yang digunakan dalam pelaksanaan penelitian ini yakni metode kualitatif. Teori yang diaplikasikan yakni teori sastra khususnya teori mengenai unsur intrinsik drama oleh Diniejko (2010) dan kritik sosial oleh Rapaport (2011). Hasil dari penelitian ini yakni, pertama, unsur-unsur intrinsik yang ditemukan yaitu plot, tokoh, dialog, latar, konflik, tema dan motif yang memberikan pemahaman mendalam mengenai film tersebut dari segi internal. Kedua, dengan melaksanakan kritik sosial terhadap film tersebut, ditemukan bahwa film tersebut berhubungan dengan kondisi sosial Amerika pada tahun 1962 dan berkorelasi dengan situasi yang diihadapi oleh masyarakat berkulit putih dan hitam di Amerika.
\end{abstract}

Kata Kunci: intrinsik, kritik, berbeda, ras putih, ras hitam

\section{INTRODUCTION}

Inequality among black and white in United States of America has been an issue which is discussed from time to time and often depicted in various literary works. One of those literary works is a movie. Stevenson (2018: 488) said that a movie is a powerful medium to popularly and scholarly portray an image of history. The portrayal of Black American in a movie has been done from several past decades (Redden, 1964; Johnson, 1965).

There are some previous studies discussing about a portrayal of certain people, society, and life such as what is 
done by Li (2014), Rakhshandehnia et al. (2016), Fakhrurrazi et al. (2018), Marliana et al. (2018), and Ramanathan (2018). However, to be more specific related to the issue discussed in this study, a study discussing about an American movie portraying about the inequality mentioned previously is a sociological approached study done by Hidayatullah (2016). Her study used Twelve Years a Slave movie directed by Steve McQueen and released in 2013 as the data. It is a biographical-historical movie adapted from a real experience of Solomon Northup, an independent slave who must live under slavery for twelve years during 1840s. Trying to send a message to society, the Twelve Years a Slave movie succeeds in getting response from various people especially critics. However, instead of conveying the message of the movie, her study used the sociological approach to convey the description of people in the past.

Concerning the phenomenon above, the new study examines a movie which has similar case as Twelve Years a Slave Movie. It is a biographical comedydrama movie which is set in 1962 telling about a true friendship of an AfricanAmerican and an Italian-American entitled Green Book. This movie, as it is released in 2018, is also taken as the example of what must and must not be done by American society in solving the problem of superiority and inferiority of white and black American. Hence, the meaning of message delivered in the movie should be understood well.

Therefore, different from the previous study which used the sociological approach to convey the description of how people during the past era, this study focused on using the sociological approach to convey the meaning of the movie by concerning the social background of both eras (the one during 1962 and one of nowadays era). Hence, the correlation between the movie which tells about something happened in 1962 and the condition of American society nowadays can be known and the meaning of the movie can be understood. Therefore, in order to do so, the sociological criticism is applied in the study. Moreover, in understanding a movie, the intrinsic elements of the movie must also be known (Indriani et al., 2019). Hence, the intrinsic elements of the movie are also analyzed to have the understanding of the movie itself. Since no one has conducted an analysis of both intrinsic elements and sociological criticism of Green Book movie, the new study is needed to be conducted.

Based on the foregoing phenomena discussion, the problems of the study were formulated as follows.

a What are the contents of intrinsic elements found in the Green Book movie?

b How is the Green Book movie criticized from sociological perspective?

\section{MATERIAL AND METHOD}

This is a library research. It analyzed data in the form of text and image. Therefore, it applied qualitative method.

The data of the study was primary data. It is an audio-visual data of Green Book movie and the script of the movie. The movie is written by Vallelonga, Currie, and Farrelly in 2018. It is directed by Farrelly. It is produced by Participant Media, Dream Works Pictures, Innisfree Pictures, Cinetic Media, and Alibaba Pictures in United States of America. This movie duration is 130 minutes.

The data was collected by using documentation method and recording technique. The recording technique of both audio-visual and document materials was done by taking a note. The steps of colecting the data were firstly by downloading the movie and finding out the Green Book movie script; secondly, 
the movie which had been downloaded was watched and the script of the movie was read, furthermore, the important parts related to the problems of the study were jotted down.

The collected data was analyzed in qualitative method based on the theory of literature specifically the intrinsic elements of drama proposed by Diniejko (2010) and sociological criticism proposed by Rapaport (2011). The first step of analyzing the data was organizing all data. Furthermore, all organized data was read thoroughly. After that, they were coded in order to gain a description. The next step was interpretation of the intrinsic elements and sociological criticism.

\section{THEORETICAL BASIS}

This study aplies Theory of Liteature. This theory is chosen to be the basis of the study. It is specifically about intrinsic elements of drama proposed by Diniejko (2010) and sociological criticism proposed by Rapaport (2011).

\section{A Intrinsic Elements}

According to Diniejko (2010: 253), intrinsic is "interior; approaches to literary works which depend solely on literary criteria". Hence, the term intrinsic element used in the study refers to the internal elements of Green Book movie. It is the elements of drama consisted of story and plot, characters, dialogue, monologue, and soliloquy, theme and motif, conflict, and setting and staging. The elements of drama is used because drama has similar feature as movie.

\section{B Sociological Criticism}

Rapaport (2011: 11) explain that, in understanding a literary work, it is not only the content of the work that should be analyzed, but also the social content in everyday life. That social content can be some issues such as inequality, relations of social power, as well as victimhood which is depicted in the literary work. The Green Book movie is also understood by looking at those social contents.

\section{RESULT AND DISCUSSION}

\section{A. Intrinsic Elements of Green Book Movie}

The analysis on the contents of intrinsic elements of Green Book movie as what is proposed by Diniejko (2010) is presented in this section. The explanation is started from the plot, characters, dialogue, setting, conflict, until the last one is the theme and motif. Bellow is the further explanation.

\section{a Plot}

Based on the explanation of Diniejko (2010: 83), Green Book movie is categorized to have an episodic structure plot. This structure is shown by the use of many characters and locations and some parallel plots in the movie. As Lip and Dr. Shirley are told to have an eightweeks journey, the scenes when they are in some different countries to South take different characters and settings.

\section{b Character}

The characters of the Green Book movie are the two main characters who have dynamic character: Frank "Tony Lip" Vallelonga who is the protagonist of the movie and Dr. Donald Shirley has some contrast characteristics compared to Lip psychologically and phsycologically. The rests are static characters such as Dolores, Jules Poddel, Joey Loscudo, Oleg Mallakov, Amit, and American societies whom the two main characters met during their trip to Deep South of United States of America.

\section{c Dialogue}

Dialogue is one of the important parts in Green Book movie. As what has been stated by Diniejko (2010) in the previous chapter, it is because the 
dialogue has some functions. Look at the example below.

\section{Data 1}

PATROLMAN \#1: "Oh, now I get it. That's why you driving this boy around... you half a nigger yourself."

Lip slams patrolman \#1 with an uppercut, dropping him like a stone.

PATROLMAN \#2 pulls his revolver on lip.

POLICEMAN \#2: (shaking) "Hands in the air, now!"

(Vallelonga et al., 2018: 85)

Looking at the example above, it can be seen that if the policeman does not tease Lip due to his last name, Lip will not feel offended and hit him that causes Lip and Dr. Shirley have to be jailed for few hours in Mississippi. It shows how utterances influence the action of the characters. That action affects the plot of the movie. Hence, the first function of dialogue in Green Book movie which is found is to advance the plot.

\section{Data 2}

LIP: "He's not gonna miss any shows."

RECORD EXEC: "Good. And you're going to need this."

He hands Lip a small GREEN BOOK.

RECORD EXEC: (CONT'D) 'It's the book I told you about. Sometimes you're staying in the same hotels, and sometimes you're not."

As Lip glances at the book, we -

(Vallelonga et al., 2018: 24-25)

The second function of dialogue can be seen in the movie is to foreshadow an event in the movie. The dialogue above is taken when the record exec gives Lip The Negro Motorist Green Book. By stating that Lip must need the Green Book during the journey to the South. That book is called to be a guidance for Black in having a trip in America. From that dialogue, the audiences are clued that there must be a problem related to the different accomodation that can be used by Dr. Shirley since he is a Negro. As what is expected, the story goes to tell the inequality experienced by Dr. Shirley and he must be in a place that accepts him as what has been listed in the Green Book.

\section{Data 3}

DR. SHIRLEY : "Have you ever thought of being a food critic?"

Lip looks up, hopeful.

LIP : "Not really, but...why? Is there money in that?"

(Vallelonga et al., 2018: 32)

The third function of dialogue found in the movie is to reveal a character. Through utterances spoken, the character's characteristics can be revealed. It is set when they have dinner together in Pennsylvania. It can be seen that Lip is a type of person who simply says what he thinks and wants to say. With his narrow mind set about world, he thinks that the more important thing in doing a stuff is the money. It can be concluded from the dialogue that Lip is a blunt, unwell educated, and money oriented person.

Data 4

MORGAN ANDERSON: "Are you looking for the commode? Here, let me help you."

He leads Shirley to a back door, opens it. MORGAN ANDERSON: "It's right out there "fore the pines."

Shirley looks out, sees an old OUTHOUSE at the edge of the woods.

DR. SHIRLEY: "I'd rather not use that." (Vallelonga et al., 2018: 63-64)

The fourth function is that the dialogue in the Green Book can reveal the moods of the characters. Whether the characters are in a good or bad mood can be seen from the words they utter as well as its intonation. From the data 4, it can be seen that Dr. Shirley's mood which is previously good turns to be bad when Anderson offers him to use a commode 
that is far from the word 'suitable' for human. His bad mood is revealed when he refuses to use that commode and rather chooses to use what he has in his motel room. He feels bad for being discriminated like that.

\section{Data 5}

DR. SHIRLEY : "Tony, when we arrive in a city, the first thing I'd like you to do is check the piano where I'm playing. Make sure it's a Steinway as per my contract."

Lip pulls out a pen, writes "STAIN WAY" on the map.

(Vallelonga et al., 2018: 29)

\section{Data 6}

\section{DR. SHIRLEY : :II.. I really can't do this." \\ LIP : "Eat the goddamn thing."}

Shirley takes a bite. Lip can see he's enjoying it.

LIP : "What, no good? Very good."

DR. SHIRLEY : "I just... this seems so... so unsanitary."

(Vallelonga et al., 2018: 53)

The fifth function of the dialogue uttered by the characters in Green Book movie is to reveal the relationship between the characters. The movie portrays a story of two strangers that becomes friends, the change of relationship between Lip and Dr. Shirley can be known through the dialogues. Firstly, their relationship is only a relation of a boss and his driver (data 5). Their conversation is gapped by their status. However, as the time flies, they start to become closer as Lip tries to share his fried chicken, and by lowing his pride, Dr. Shirley wants to eat it for the very first time in the car without any utensils (see data 6).

\section{d Setting}

Green Book is set in 1962 as it is presented in the first scene of the movie. Specifically, it happened during some weeks before and until the Christmas Day in 1962. The setting of place is mainly in United States of America as it is set in New York, the place Lip and Dr. Shirley lived and worked, and some other states such as Pennsylvania, Ohio, Indiana, Kentucky, North Carolina, South Carolina, Georgia, Tennessee, Mississipi, and Alabama as the places the Don Shirley Trio hold concert during their trip to the South. Being set in the United States of America makes this movie relevant to bring the issue of White and Black people up. Due to the clear statement stated in the movie, audiences can be directed to know and understand who and what are portrayed in the movie.

\section{e Conflict}

Concerning what is explained by Diniejko (2010: 86), every story must contain one or some conflict(s) that should be solved. The main conflict in the Green Book movie is the conflict of ideas. It is because the idea of how to treat minority group in America especially Black American becomes the issue that has to be fixed. That idea is thought differently by Lip, Shirley, and the common American society.

Portraying the clash of idea, there are two types of conflict found in the movie: person against person and person against society. Firstly, the conflict of person against person is shown when Lip and Dr. Shirley argued about what each of them thought about the issues they faced and experienced such as the use of better diction, music, eating fried chicken, until who was more black than whom. Secondly, the conflict of person against society is described when Lip and Dr. Shirley fought against the American society for the tradition they built that limited the access of Black American to get a same treatment.

\section{f Theme and Motif}

Concerning at what has been explained in the previous elements of 
Green Book movie, there is one important point that can be noted that the movie tells about differences. To be specific, it shows the differences between White American and Black American. The difference revealed in the movie is not merely about the color of their skin, but also their culture and the way they are treated by society. From the idea of 'being different', the story begins. The author portrays the difference by comparing two characters represented White American and Black American. In the movie, Lip, whose economic status is lower than Dr. Shirley, is described as someone who gets better treatment in terms of facilities and society responses than Dr. Shirley because he is White while Dr. Shirley is Black. However, that difference is the beginning of their story. It leads them to the conflict among themselves and society. It changes them to appreciate each other and become friends. Therefore, a difference cannot only be considered as a factor to separate someone from the others, but it is also as a factor to unite them.

It can be concluded that there are two major topics that become the idea of the movie: difference and friendship. If those two major topics are specified, the theme of the movie can be obtained. The theme is the difference cannot stop someone to unite and be friend with the others.

The motif of the movie is the incident of white versus black that is recurringly portrayed. That incident is the debate between Shirley and Lip and the two of them with the other White Americans they met during the trip. It is resulted from the unequal treatment they gave to Shirley. This motif specifically shows the difference between a major race and one of minor races existing in America. This helps the elaboration of the theme in the movie.

\section{B Sociological Criticism on Green Book Movie}

Data 7

REDNECK \#1: "You come in here for a drink? Then you must be tired of livin', boy."

(Vallelonga et al., 2018: 57)

Data 8

MORGAN ANDERSON : "Are you looking for the commode? Here, let me help you."

He leads Shirley to a back door, opens it. MORGAN ANDERSON : "It's right out there "fore the pines."

(Vallelonga et al., 2018: 63)

Data 9

The Tailor REACTS, follows Shirley toward the dressing room.

TAILOR : "Uh, excuse me, you're not allowed to try that on."

(Vallelonga et al., 2018: 71)

Looking at those dialogues above and the examples given in the previous section, there must be a question risen up in response to the unequal treatment given to Dr. Shirley as black. The movie portrays that during the journey, Dr. Shirley used to hear the expression of prohibition directed to him when he entered some places dominated by white and get unequal facility in comparison to what is given to the white. Moreover, it is not only him who is treated distinctively, the other blacks as well. It is seen when Vallelonga's family tried to keep Dolores who handled two black workers in their appartment. It is enough to show that black is thought to be such a harmful person. The reason behind those inequalities must be known well in order to fully understand the message of the movie.

Confirming the case of inequality faced by Dr. Shirley as Black American in the Green Book movie, the history that has been the background of that phenomenon is firstly presented in this 
part. According to Datesman et al (2014: 183 ), it was started from the arrival of Americans of African descendant in United States of America because they were sold to be slaves.

Being slaves of White Americans, the most dominant ethnic, made them be in a low position in society. Andrews (2006: 36) states that Black American is a compacted society who fights to get freedom and equality against a dominant and thoroughly hostile White American. The enslavement, furthermore, was a complete contradiction in the United States. The US was divided into two: (1) Northern States which chose to abolish slavery; and (2) Southern States which supported black slavery and used it as the basis of the economy. The clash of those two sides of state, furthermore, resulted in Civil War between the North and the South from 1861-1865 in which the North won and slavery ended in the United States.

Datesman et al (2014: 184) further explain that the end of the Civil War cannot erase the legacy of black slavery in America. African Americans were not ready to assimilate into the larger American culture. In the North, the Blacks continued to be the victims of strong racial prejudice. Being worse than what happened in the North, in the South, Blacks experienced segregation. They were not allowed to vote, attend public school, receive a good education as what the Whites were. African Americans at that time had very limited opportunties for higher education (Kim, 2002: 385). Datesman et al. further explain that they were not allowed to compete equally in the White-dominated society. They even were caught in poverty and continued for generations.

The unequal treatments mentioned above made the Black Americans started the Civil Right Movement in 1950s until 1960s. Hence, the two decades are called as a turbulence and social change by
Fiedler et al (1990: 112). The Black Americans became politically active as they brought their protests to the streets and courts all over the country struggling their will to get the freedom and the equality of opportunity.

Looking at the timeline, it can be seen that during 1962, the African Americans were still in a period of struggling in the Civil Rights Movement. Therefore, in line with the vision of the other Black Americans to change the society to give them freedom and equality of opportunity, Dr. Shirley did a brave action to conduct concert tour to South States in the Green Book movie. He knew that the Whites in the South must be ruder in treating him than those who were in the North. It was because in the South they were not merely prejudiced, but also segregated. Therefore, he needed a handy man like Lip to be his chauffer during the journey which later made them be friends.

Moreover, the case of segregation caused the Black American create a guiding book for having safe journey. That book is called as "The Negro Motorist Green-Book" or shortly known as "Green Book". The book is used to lessen a shameful situation in travel and protect travelers from physical harm by providing the list of places served for African American travelers without discrimination (Hall, 2014: 307). The term "Green Book", as it is decided as the title of the movie, can be seen as the symbolic portrayal of the hard journey of the Black Motorist during the era of racial segregation in the United States. It was, therefore, very useful for Lip to drop Dr. Shirley to some places accepting him.

Furthermore, according to Datesman et al. (2014: 185), the movement of the Black Americans, furthermore, resulted in some changes especially in making segregation of public facilities illegal and giving the Black people the right to vote 
in elections. Datesman et al. (2014: 185) add that it brought a significant degree of assimilation of African Americans into the larger American cultures. It decreased the level of prejudice towards the Black Americans in all over states in America.

However, being reduced does not mean that the prejudice towards the Black American has been erased. Vancoillie (2018: 42) finds that recently African Americans are still discriminated in the labor, housing and consumer markets and keep being confronted with disparities in income and wealth. Based on the result of a survey conducted by National Public Radio, the Robert Wood Johnson Foundation, and Harvard T.H. Chan School of Public Health in 2017, 92 percent of the African Americans believe that the discrimination against them still exists today in America. The 49 percent say that the discrimination is based on the prejudice of the individual people, 25 percent say that it is caused by laws and government policies, and the rests mention both of the two reasons. Additionally, Bobo (2011) adds that American today also inhabits an unsettled place as similar as in the past: situated somewhere between the discrimination of the segregation era and the aspiration of full racial equality.

The African Americans indeed get the same chance to study until they achieve the highest degree of education. Wilson (2018) found that in 2016, 92.3 percent of the African American adults (age 25-29) were high school graduates with 22.8 percent continued to complete the bachelor's degree or higher (up from 9.1 percent in 1968). It proves how the Blacks can have better education than before. However, Wilson (2018) argues that education is not enough to eliminate racial economic inequality. The case of race too often remains as factor to decide the economic status of African Americans in comparison to the Whites. It is found that in 2017 the Africans
Americans with advanced degrees of education still had an unemployment rate that was higher than whites who only have a bachelor's degree and those with a bachelor's degree had an unemployment rate closer to the unemployed whites with only a high school diploma rate (Wilson, 2018). Long (2017) even reported that, based on U.S. Census Bureau data, the African Americans household average income was $\$ 39,490$ in 2016 lower than the amount in 2000 which was $\$ 41,363$ (the nominal of both figures is in 2016 dollars, so they have been adjusted for inflation).

The case of inequality nowadays is made worse by the election of Trump as American president in 2016. According to Ricard (2018), Trump's victory is said as an elevation to the political misfit of Obama's presidency as he supports the voice of all whites like how the previous America should be. Therefore, the transition of Obama presidency to Trump makes American as if back to how they used to be: based on white supremacy.

Looking at the fact that the African Americans until today still experience inequality specifically in economic sector because of being prejudiced, the reason why the portrayal of inequalities faced by Black American during 1962 shown in the Green Book movie which is produced in 2018 can be understood. The movie is made to remind the Americans about how hard and painful it was to fight against segregation in the South during the Civil Right Movement era. The story of the movie is also relatable to the condition of the Blacks and the Whites nowadays. Considering this condition, the message delivered in the movie in solving the racial inequality case is as that the Whites should stop the prejudice and start to respect the racial differences between the Whites and the Blacks. They also should interweave a friendship relation to each other and live in harmony. 


\section{CONCLUSION}

Based on the analysis above, it can be concluded that, firstly, the intrinsic elements found in the Green Book movie are plot, character, dialogue, setting, conflict, theme and motif. The plot structure of the movie is episodic. Secondly, by conducting a sociological criticism on the Green Book movie, it is found that the movie depicts the social reality faced by American during 1962, the segregated South era, and it has correlation with what happens nowadays in America. In both eras African Americans face inequalities in getting the opportunity to work and it is due to the personal prejudice towards them. Furthermore, the message of the movie to the society is that one way to solve the case of inequality is that prejudice should be stopped. The white should start to direct their mind to more respect the racial difference of white and black and rather interweave a friendship relation in order to achieve the equality.

\section{REFERENCES}

Andrews, M. (2006). In The Shadow of the Eclipse of White America. Society. 43(5), pp35-38.

Bobo, L. D. (2011). Somewhere between Jim Crow \& Post-Racialism: Reflections on the Racial Divide in America Today. The American Academy of Arts and Sciences. Vol. 140, Issue 2, pp11-36.

Datesman, M. K., Crandall, J., and Kearny, E. N. (2014). American Ways: An Introduction to American Culture $4^{\text {th }}$ Edition. Pearson, New York.

Diniejko, A. (2010). Introduction to the Study of Literature and Film in English. Uniwersytet Warszawski, Warszawa.
Fakhrurrazi, Basid, A., and Hamzah, M. Z. (2018). The Value of the Struggle of Difabel Children in Film Jembatan Pensil Based on Perspective of Sociology of Literature. Advances in Social Science, Education and Humanities Research. 280, pp430-438.

Fiedler, E., Jansen, R., and NormanRisch, M. (1990). America in Close-Up. Longman, Essex.

Hall, M. R. (2014). The Negro Traveller's Guide to a Jim Crow South: Negotiating Racialized Landscapes during a Dark Period in United States Cultural History, 1936-1967. Postcolonial Studies. Vol. 17, No. 3, pp307-319.

Hidayatullah. (2016). Slavery in Steve McQueen's Movie '12 Years a Slave' (skripsi). State Islamic University of Alauddin, Makasar.

Indriani, D., Sili, S. and Ariani, S. (2019). An Analysis of Intrinsic Elements in Mama Film by Andres Muschietti. Journal Ilmu Budaya. Vol. 3, No. 1, pp13-14.

Johnson, A. (1965). The Negro in American Films: Some Recent Works. Film Quarterly. Vol. 18, No. 4, pp14-30.

Kim, M. M. (2002). Historically Black vs. White Institutions: Academic Development among Black Students. The Review of Higher Education. Vol. 25, No. 4, pp385407.

Klarer, M. (1999). Introduction to Literary Studies. Routledge, New York. 
Long, H. (2017). African Americans Are the Only Racial Group in U.S. still Making Less than They Did in 2000 [Internet]. The Washington Post, Available from: https://www.washingtonpost.com/n ews/wonk/wp/2017/ 09/15/africanamericans-are-the-only-racialgroup-in-u-s-still-making-less than-they-did-in-2000/. [Accessed on October 3, 2019].

Marliana, R., Arafah, B., and Herawaty. (2018). Convicts Life in James Tucker's The Adventures of Ralph Rashleigh. ESL-Journal on Interdisciplinary Studies in Humanities. 1(1), pp76-82.

National Public Radio, the Robert Wood Johnson Foundation, and Harvard T.H. Chan School of Public Health. (2017). Discrimination in America: Experiences and Views of African Americans. Available from: https://www.npr.org/assets/img/201 7/10/23/discriminationpoll-africanamericans.pdf. [Accessed on October 4, 2019]

Rakhshandehnia, S. A., Chafjiri, H. S., Hosseini, S. E., and Niaki, A. (2016). Sociological Criticism of the Novel "Abdul Motajali's Confessions" by Najib Al-Kilani. Medwell Jornal on the Social Sciences. 11 (9), pp2018-2022.

Ramanathan, J. (2018). Literature as a Key to Understanding People, Society and Life. Cadmus. 3(4), 3956.

Rapaport, H. (2011). The Literary Theory Toolkit: A Compendium of Concepts and Methods. WileyBlackwell, West Sussex.
Redden, C. L. (1964). The American Negro: An Annotated List of Educational Films and Filmstrips. The Journal of Negro Education. Vol. 33, No. 1, pp79-82.

Ricard, S. (2018). The Trump Phenomenon and the Racialization of American Politics. Revue LISA/LISA E-Journals. Vol. XVI, No. 2. DOI: 10.4000/lisa.9832.

Stephanie Li. (2014) 12 Years a Slave as a Neo-Slave Narrative. American Literary History. Vol. 26, Issue 2, pp326-331.

Stevenson, B. E. (2018). Filming black voices and stories: Slavery on America's Screens. The Journal of the Civil War Era. 8(3), pp488520,560 .

Vancoillie, L. (2018). How Did Racial and Socio-economic Inequality in the United States Contribute to Donald Trump's Election? (Dissertation). Ghent University, Ghent.

Wilson, V. (2018). 50 Years after the Riots: Continued Economic Inequality for African Americans [Internet]. Economic Policy Institute, Available from: https://www.epi.org/blog/50-yearsafter-the-riots-continued-economicinequality-for-african-americans/. [Accessed on October 6, 2019]. 